\title{
The Perceptions of Islamic Career Prospects of Senior High School Students
}

\author{
Hartono \\ Email: hartono140@yahoo.com \\ Lecturer of Guidance and Counseling Departement, \\ Surabaya PGRI Adi Buana University
}

\begin{abstract}
Islamic senior high school students' career prospects are an important issue to be studied in the global society. The study was conducted through a descriptive survey study involving 188 senior high school students of the eleventh-grade of Islamic educational institutions in the region of Surabaya. The research data was collected by using questionnaire method and analyzed with descriptive statistical analysis techniques. The findings of this study show that $90.96 \%$ of respondents regard that Islamic career prospects are good based on the criteria of promotion, $87.77 \%$ of respondents regard that Islamic career prospects are good based on the criteria of aspirations, $83.51 \%$ of respondents regard that Islamic career prospects are good based on the criteria of career goals, $80.32 \%$ of respondents regard that Islamic career prospects are good based on the criteria of compensation, and $72.87 \%$ of respondents regard that Islamic career prospects are good based on criteria of sustainability.
\end{abstract}

(c) 2013 Published by Adi Buana University Press

Keywords: perception, prospects, and career of islamic.

\section{Introduction}

Islamic career prospects today received special attention in the wider community. This phenomenon is developing in line with the progress of Muslims in creating and developing the economy system based on Islam's religious values. The global community recognizes this influence, thus encourages the strengthening of the existence of Islamic career in public life. As an illustration, the widespread network of syariah banking proves that the building aspect of the economic system of Islami have received public trust, which fosters the development of Islamic education in Islamic educational institutions.

Findings of research of Calkins, Callahan, Houlemarde, Ikpa, Jones and King (2011) on 100 Muslim students from various countries in Indiana University, showed that they have a positive perception of the progress of the profession or work in the Islamic world. Islamic career is advancement of Muslims in the profession or various areas of work that are built based on the values of the religion of Islam. The results of research by Hartono to 193 the eleventh senior high school students in some Islamic educational institutions as his respondents in Surabaya found that $37.31 \%$ of respondents chose social career field that is related to the field of career services to humans (human service), such as teachers, lecturers, psychologists, nurses, counselors, doctors, midwives, 
social workers, dampening the conflict, and the leader, on the grounds that the field is believed to work as a source of work activities that can bring good deeds, the deeds which bring reward (Hartono, 2010b).

Career is a way of life and the purpose of life. As a way of life, a career directs Muslims to do business in the way of God by utilizing its potential, the facilities, and seize the opportunities that exist, to hope that a goal is believed to be good. As the process of life, Muslims believe that success in a career is determined by the interaction of internal factors and external factors from the environment. For the purpose of life, a career of teaching as a vehicle of worship is believed to run a command of God that comes from the teachings of al-Qur'an and al-Hadith.

According to Ann Roe whose theory is based on the needs of (a needs approach), individual career fields are grouped into two categories: careeroriented fields of services to the people (person-oriented) and the category of career fields that are not oriented to human services (nonperson-oriented) (Zunker, 2002). Both of these career fields in Islamic studies of Islamic community are believed as a career field that brings virtue when built on the values of Islam, while the career fields that give rise to immoral acts will be avoided by Muslims. Immoral acts are reprehensible deeds because it violates God's command. In other words, one's perception of Islamic career prospects also help foster career development of Islamic society.

Lilik Hendrajaya (2012) at the workshop on the theme of self-sufficiency of college paradigm has stated that there are ten factors that affect the performance of one's work ethic: (1) a boon work, (2) work is the mandate, (3) work is worship, (4) work is a living, (5) work is passion and sweat, (6) work is productivity, (7) employment is sincerity honesty in working together to benefit, (8) the dignity of work is a discipline, (9) working to build the nation, and (10) working to build and strengthen. These factors are built on the values of Islam that are derived from the al-Qur'an and al-Hadith. As God says in surah of Al Baqarah of ayat 269, God gives wisdom to whom He pleases, and whoever given wisdom, it really has given a lot of virtues, and no one can take lessons but the people who have sense. In addition, ayat 278 of surah Al Baqarah cites that for those who believe, God does command and leave the remains of usury, if they are those who obediently to God (Hartono, 2010b).

The Islamic career prospects are Muslims' view of Islamic career advancement in the future that is an important aspect in life. It is indicated by a change in career which is better than the current conditions based on the perception of Muslims. There are five criteria used to determine the Islamic career prospects, namely: career goals, aspirations, compensation, promotion systems, and sustainability (Hartono, 2010a). Islamic career goal is to be geared towards the Muslims in a field of career or job. Islam is the hope of career aspirations or desire or will of the Muslims to achieve a career field. Career field in accordance with Islamic aspirations of Muslims is a career field that is expected or desired by Muslims. The Islamic career field forward is seen as a prospective career field. Compensation related to remuneration derived by Muslims for his dedication to a career field includes salary, benefits, insurance, pensions or severance pay, and 
other legitimate income. Promotion system acts as a social rule that is used to increase the Islamic career path. A career field that has the rules accountable (clear and transparent) will be creating a conducive working environment so that Muslims are considered more prospective. Sustainability relates to the continuity of a career field of Islamic life. Career field that has seen long-term sustainability is more prospective than a career field that sustainability is uncertain (Hartono, 2010a).

Senior high school students in the Islamic educational institutions are at the end of the period of adolescent development at the age of 16-18 years (Lerner, 2006). In that period, adolescents have emotional sensitivity to a career field. They want someday to achieve a career field that has a good prospect based on his perception. According to Bekkering et. al in Prinz and Hommel (2002) the individual's perception on a career field will shape the attitudes and behaviors of both commitments and efforts to avoid or achieve the career field. When people have a positive perception in a career field of Islam, they have a strong commitment and try to grab the career field, whereas if they have a negative perception, they will avoid it.

Based on the above description, it can be concluded that the perception of students toward Islamic careers is an important aspect to be studied through research of which the results can be very useful as a reference to one's career coaching business among senior high school students in Islamic educational institutions as well as among the general public. If at the initial stage the students received adequate career guidance, their emergence will be obtained as follows. (1) Students avoid trouble of self-knowledge, (2) Students avoid trouble of doing career exploration, (3) Students avoid trouble of career-knowledge, and (4) Students avoid trouble of career decisions making.

\section{Methods}

This study is a descriptive survey research that aims to describe the perceptions of senior high school students of Islamic career prospects (Lodico, Spaulding, and Voegtle, 2006). The population covers the senior high school students of grade XI in islamic educational institutions in the Surabaya region constisting of approximately 942 students. The samples were assigned by using the technique of random sampling (Gall, Gall, and Borg, 2003). The procedure is done to take samples is as follows. First, it is to determine the four Islamic senior high schools in Surabaya of northern region, one in Surabaya of middle, and two in Surabaya of south region. Second, it is to determine the representative sample size that is $20 \%$ of the whole population. Third, it is to compile a list of members of the population consisting of 24 parallel classes. Fourth, do the random sampling of the population, in order to obtain 188 students as the study sample. In more detail, the study samples are described in table 1 as follows. 
Table 1

Research sample on Students of Class XI in Islamic Education Institutions at Surabaya

\begin{tabular}{|c|c|c|c|c|}
\hline \multirow{2}{*}{ No. } & \multirow{2}{*}{ Senior high school area } & \multicolumn{2}{|c|}{ Sex } & \multirow{2}{*}{ Total } \\
\hline & & Male & Female & \\
\hline 1. & North Surabaya & 42 & 63 & 105 \\
\hline 2. & Central Surabaya & 15 & 20 & 35 \\
\hline 3. & South Surabaya & 20 & 28 & 48 \\
\hline & Total & 77 & 111 & 188 \\
\hline
\end{tabular}

The research data were students' perceptions of Islamic career prospects collected using a questionnaire (Thomas, 2003). The questionnaire was developed by the authors using the procedure of content validity. Questionnaire items contain statements that are built based on the five criteria of Islamic career prospects, namely: (1) career goals, (2) aspiration, (3) compensation, (4) promotion system, and (5) sustainability. The questionnaire was tried out to 34 respondents of senior high school students in Surabaya at Islamic educational institutions outside the study sample (Sommer and Sommer, 1991). The try-out was intended to obtain feedback from respondents in order to tailor the use of language that can be understood by the respondents, and also aims to calculate the number of Cronbach's Alpha reliability coefficient (Singer, 2009). The test results are used to revise the questionnaire items especially in the use of the Indonesian spelling adjustments that can be understood by the respondents, as well as to calculate the reliability coefficient of Cronbach's Alpha. The data of questionnaire after the trial results were analyzed with the help of the application program of SPSS for Windows version 16.0, the obtained Cronbach's Alpha reliability coefficient was .915 .

The data were analyzed using descriptive statistics with the formula $\mathrm{P}=\mathrm{f} / \mathrm{N} \times 100$, where $\mathrm{P}$ is the percentage, $\mathrm{f}$ is the frequency, and $\mathrm{N}$ is the number of members of the sample, to calculate the percentage of respondents' answers.

\section{Results}

The respondents' perceptions of senior high school students in Islamic educational institutions in the city of Surabaya concerning Islamic career prospects based on criteria of career goals, aspirations, compensation, promotion, and sustainability, are described in table 2 to table 7 as follows. 
Table 2

Respondents’ perception on Islamic Career Prospects based on Job objective criteria

$(\mathrm{N}=188)$

\begin{tabular}{lcc}
\hline Respondent' response & Frequency (f) & Percentage (\%) \\
\hline A. Good & 157 & 83.51 \\
\hline B. Fair & 24 & 12.77 \\
\hline C. Poor & 7 & 3.72 \\
\hline Total & 188 & 100 \\
\hline
\end{tabular}

Based on table 2 above, 157 respondents or $83.51 \%$ answered good prospect, 24 respondents or $12.77 \%$ answered fair prospect, and only 7 respondents or $3.72 \%$ answered poor prospect. Most of the respondents (83.51\%) stated that based on the criteria of career goals, prospects of Islamic career, is good.

Table 3

Respondents’ perception on Islamic Career Prospects based Aspirations Criteria

$(\mathrm{N}=188)$

\begin{tabular}{lcc}
\hline Respondent' response & Frequency (f) & Percentage (\%) \\
\hline A. Good & 165 & 87.77 \\
\hline B. Fair & 13 & 6.91 \\
\hline C. Poor & 10 & 5.32 \\
\hline Total & 188 & 100 \\
\hline
\end{tabular}

Based on table 3 above, 165 respondents or $87.77 \%$ answered good prospect, 13 respondents or $6.91 \%$ answered fair prospect, and only 10 respondents or 5.32\% answered poor prospect. Most of the respondents (87.77\%) stated that based on the criteria of aspirations, prospects of Islamic career is good.

Table 4

Respondents’ perception on Islamic Career Prospects based Compensation Criteria

$(\mathrm{N}=188)$

\begin{tabular}{lcc}
\hline Respondent' response & Frequency (f) & Percentage (\%) \\
\hline A. Good & 151 & 80.32 \\
\hline B. Fair & 20 & 10.64 \\
\hline C. Poor & 17 & 9.04 \\
\hline Total & 188 & 100 \\
\hline
\end{tabular}

Based on table 4 above, 151 respondents or 80.32\% answered good prospect, 20 respondents or $10.64 \%$ answered fair prospect, and only 17 respondents or $9.04 \%$ answered poor prospect. Most of the respondents (80.32\%) stated that based on the criteria of compensation, prospects of Islamic career is good. 
Table 5

Respondents’ perception on Islamic Career Prospects based Promotion Criteria

$(\mathrm{N}=188)$

\begin{tabular}{lcc}
\hline Respondent' response & Frequency (f) & Percentage (\%) \\
\hline A. Good & 171 & 90.96 \\
\hline B. Fair & 9 & 4.79 \\
\hline C. Poor & 8 & 4.25 \\
\hline Total & 188 & 100 \\
\hline
\end{tabular}

Based on table 5 above, 171 respondents or $90.96 \%$ answered good prospect, 9 respondents or $4.79 \%$ answered fair prospect, and only 8 respondents or $4.25 \%$ answered poor prospect. Most of the respondents $(90.96 \%)$ stated that based on the criteria of promotion, prospects of Islamic career, is good.

Table 6

Respondents perception on Islamic Career Prospects based Sustainability Criteria

$(\mathrm{N}=188)$

\begin{tabular}{lcc}
\hline Respondent' response & Frequency (f) & Percentage (\%) \\
\hline A. Good & 137 & 72.87 \\
\hline B. Fair & 31 & 16.49 \\
\hline C. Poor & 20 & 10.64 \\
\hline Total & 188 & 100 \\
\hline
\end{tabular}

Based on table 6 above, 137 respondents or $72.87 \%$ answered good prospect, 31 respondents or $16.49 \%$ answered fair prospect, and only 20 respondents or $10.64 \%$ answered poor prospect. Most of the respondents (72.87\%) stated that based on the criteria of sustainability, prospects of Islamic career is good.

Table 7

Ranking of Percentage of Respondents’ Good Answer on Islamic Career based on the Five Criteria

$(\mathrm{N}=188)$

\begin{tabular}{cccc}
\hline No. & Criteria & Ranking & Percentage (\%) \\
\hline 1. & Promotion & 1 & 90.96 \\
\hline 2. & Aspirations & 2 & 87.77 \\
\hline 3. & Objective & 3 & 83.51 \\
\hline 4. & Compensation & 4 & 80.32 \\
\hline 5. & Sustainability & 5 & 72.87 \\
\hline
\end{tabular}

According to the table 7 above, 188 respondents or senior high school students in Islamic educational institutions in Surabaya, as much as $90.96 \%$ Islamic career prospects looked good based on the promotion criteria, 87.77\% Islamic career prospects looked good based on the aspirations criteria, 83.51\% 
Islamic career prospects looked good based on the objective criteria, 80.32\% Islamic career prospects looked good based on the compensation criteria, and $72.87 \%$ islamic career prospects looked good based on the sustainability criteria.

\section{Discussion}

Islamic career prospects is the view of Muslims in the advancement of career in accordance with the teachings of the religion of islam. The Islamic career prospects of Islamic are considered important to study from the perception aspects of senior high school students in the educational institutions of Islam, because the results of this study are very useful especially for guidance and counseling teachers/counselors in schools to provide adequate career guidance service to students. The perceptions of students serve as an important aspect, because it determines the attitude and behavior of students in the form of efforts to avoid or achieve a career field. When a student has positive perception relating to prospect of a career field, the attitude and behavior will be directed to achieve the career field aspired. Conversely, if a student has negative perception concerning career fields, the attitude and behavior are directed to shy away from a career field that is not preferred. The results of research by Hartono on 193 respondents or senior high school students of class XI in Islamic educational institutions in Surabaya, it was found out that $37.31 \%$ of respondents chose social career field, with reason that the career field is believed to be the source of the work activities that can bring good deeds, the deeds that bring rewards (Hartono, 2010b). Social career field is the field of career-related services to the people (human service), such as teachers, lecturer, psychologists, nurses, counselors, doctors, midwives, social workers, dampening the conflict, and the leader of the people.

Islamic prospective career fields, as previously-mentioned, are indicated by the change in conditions which is better than current career. In this study the respondents' perceptions of Islamic career prospects is based on the five criteria: career goals, aspirations, compensation (Heslin, 2003), promotion system, and sustainability (Tyrer and Ahmad, 2006). Based on the criteria of career goals, out of 188 respondents who answered good prospects, 157 respondents or $83.51 \%$, the answer fair prospect of 24 respondents or $12.77 \%$, and only 7 respondents or $3.72 \%$ answered poor prospect. Most of the respondents $(83.51 \%)$ stated that based on the criteria of career goals, prospects of Islamic career, is good, as Muslims believe, working in the field of work in accordance with the teachings of the religion of Islam, is a place of worship that brings the practice/reward. The findings of this study is supported the research by Tyrer and Ahmad on 20 respondents from Pakistani Islamic student he interviewed, they stated that the reason work on the kind of work in accordance with the teachings of the religion of Islam is to worship as Muslims liability (Tyrer and Ahmad, 2006). In other words, work is an important means to worship that God commanded his servants. As God (Allah) says in ayat 105 of surah At-Tawbah "Work for you. God (Allah) and His Messenger and the believers will see your work. And you will be returned to the Knower of the Unseen and the Visible: and He will disclose to you about what you do" (Adlany, Tamam, and Nasution, 2004). 
Based on the aspirations criteria or expectations of the people of Islam, out 188 respondents, 165 respondents or $87.77 \%$ answered good Islamic career prospects, 13 respondents or $6.91 \%$ answered fair prospect for Islam, and only 10 respondents or $5.32 \%$ replied that Islamic career prospects are poor. Most of the respondents (87.77\%) stated that the Islamic career prospects are good, because in principle the field of work/profession in accordance with the religious teachings of islam can be seen as a mandate. In view of the Qur'an, the goal is to create a trustful cooperation both among fellows. Mandate is the key to prosperity and glory of a nation, mandated as a social glue that is capable of forming a network of solidarity and networking among segments of society, in order to reach a state that has the social capital to implement democracy and peace (Pulungan, 2006). In view of the work as a mandate, then the work is important, the work of Muslims to build cooperation, both within the profession and between the profession to improve the welfare of the people.

Based on the compensation criteria, out of 188 respondents, 151 respondents or $80.32 \%$ answered good prospects, 20 respondents or $10.64 \%$ answered fair prospect, and only 17 , or $9.04 \%$ of respondents who answered the Islamic career prospects is poor. Most of the respondents (80.32\%) stated that the Islamic career prospects based the compensation criteria is good, because according to the Islamic religion, income/salary is the sustenance of God (Allah), and if the income/salary we earn kosher, then we will get a blessing. In al-Qur'an and alHadith, blessed is the perpetuation of the good, or the increase in goodness (Rafiq, 2011). It can be concluded that kosher income/salary of a profession, Muslims believe that it would bring blessing which causes happiness, prosperity, and peace in the life of mankind. It is also supported by the results of Walker and Pitts's research showing that people realize that moral character and believe in a higher power is the descriptor/sign of religious beings (Zinnbauer, and Pargament, 2005).

Based on the criteria of promotion, out of 188 respondents, 171 respondents or $90.96 \%$ answered good prospects, 9 or $4.79 \%$ of respondents answered fair prospects, and only 8 or $4.25 \%$ of respondents who answered the Islamic career prospects is poor. Most of the respondents (90.96\%) stated that the Islamic career prospects of based on the promotion criteria is good. Promotion is the process of increasing one's career to a higher level based on certain rules or procedures. Islamic career field that has a good promotion system to encourage worker of career may improve work ethics, morale, and motivation to achieve maximum performance. In ayat 2 of surah Al-Mulk of Quran, work is the nature of life, spiritual life, intellectual, physical, biological, and social and individual life in a variety of fields (Al Fath, 2009). Every person has the right to obtain such a commendable predicate potential, active, creative, dynamic, and productive to deserve to be called a professional.

To achieve maximum performance in career development, what to be considered is a good work ethic, namely: Ash-Shalah (kind and helpful), Al-Itqan (steadiness or perfectness), Al-Ihsan (do your best), Al-Mujadah (work loud and maximum), Tanafus and Ta'awun (competing and helping others), and examining the value of time (Ayyub Al Fath, 2009). Good work ethic can encourage productive system of promotion and conducive work culture, so as to obtain 
maximum quality work. Islam teaches Muslims that the work is a duty that must be carried out sincerely and correctly as a basic requirement that every work activity is worth worship. God (Allah) says in ayat 3 of surah Al-Qalam, "And verily for thee reward unfailing. And indeed you have a noble character" (Nazri Adlany, 2004).

Based on the criteria of sustainability, out of the 188 respondents, 137 respondents or $72.87 \%$ answered good prospects, 31 respondents or $16.49 \%$ answered fair prospects, the remaining 20 respondents or $10.64 \%$ answered poor prospects. Most of the respondents (72.87\%) stated that the Islamic career prospects based on the sustainability criteria well. Sustainability relates to the continuity of work life of a career. Islamic career field that has long-term sustainability of the work, accompanied by an adequate system of promotion, as well as an attractive salary system (has a basic salary, family allowances, old age benefits/pensions and other lawful income), can be seen as more prospective than the area of career other Islamic system which does not have a fixed salary. In general, areas of Islamic career that have payroll system of remains is still being done by Islamic institutions and other entities such as hospitals, Syariah bank, educational institutions, and other forms of enterprise.

\section{Conclusions}

Based on the data analysis and discussion that has been described above, the writer concluded the results of this study as follows.

1. Most or $90.96 \%$ of respondents regard Islamic career prospects are good based on the criteria of promotion;

2. Most or $87.77 \%$ of respondents regard Islamic career prospects are good based on the criteria of aspirations;

3. Most or $83.51 \%$ of respondents regard Islamic career prospects are good based on the criteria of career goals;

4. Most or $80,32 \%$ of respondents regard Islamic career prospects are good based on the criteria of compensation, and;

5. Most or $72.87 \%$ of respondents regard Islamic career prospects are good based on criteria of sustainability.

\section{Recomendations}

As a follow up of the results of this study, the writer recommend the following:

1. Perceptions of students are important aspects which contribute to form and develop attitudes and behavior in the career development of Islamic. Students who believe that Islamic career has good prospects, attitude and behavior which will be directed to achieve the career field.

2. Guidance and counseling teachers or counselors in senior high school is expected to develop guidance and counseling services in particular adequate career guidance services, to help students understand the potential business, career exploration, and career decision-making according to personal potential and career opportunities in the growing Islamic community. 
3. To support career guidance services, senior high school students in institutions of islamic education, guidance and counseling teachers or counselors, need to build a networking/collaboration, internally with the subject teacher/classroom teacher, and externally with parents/guardians of students, and institutions or other professional services related to career counseling for students.

4. In line with the Islamic culture that worked/works as a means of worship that brings the practice is rewarding good deeds, then the guidance and counseling teachers/counselors in Islamic educational institutions needs to grow and develop a culture of improved work ethic.

\section{References}

Ayyub Al Fath. (2009). Kewajiban Kerja Keras dalam Islam. Tersedia di http://www.mta-online.com.

Calkins, A., Callahan, A., Houlemarde, M., Ikpa, E., Jones, C., \& King, C. (2011). Muslim Student Experiences in the Residence Halls: A Qualitative Analysis. Journal of the Indiana University Student Personnel Association, 2011, 22-37.

Gall, M.D., Gall, J.P. \& Borg, W.R. (2003). Educational Research: An Introduction ( $7^{\text {th }}$ ed.). New York: Pearson Education, Inc.

Grant, C.A., and Sleeter, C. E. (2007). Doing Multicultural Education for Achievement and Equity. New York: Routledge.

Hartono. (2010a). Bimbingan Karier Berbantuan Komputer untuk Siswa SMA. Surabaya: University Press UNIPA.

Hartono. (2010b). Tumbuh Kembang Nilai-nilai Keislaman dalam Pilihan Karier di Kalangan Siswa SMA Surabaya. Islamica, 5, 1, 129-141.

Heslin, P.A. (2003). Self-and Other-Referent Criteria of Career Success. Journal of Career Assessment, 11, 262-286.

Lerner, R.M. (2006). Handbook of Child Psychology (6 $6^{\text {th }}$ ed.), Volume 1: Theoretical Models of Human Development. New Jersey: John Wiley \& Sons.

Lilik Hendrajaya. (2012). Paradigma Kemandirian Perguruan Tinggi. Bandung: ITB.

Lodico, M.G., Spaulding, D.T., Voegtle, K.H. (2006). Methods in Educational Research: From Theory to Practice. San Francisco: Jossey-Bass.

Nazri Adlany, Hanafie Tamam dan Faruq Nasution. (2004). “Al Quran Terjemahan”. Jakarta: P.T. Sari Agung. 
Prinz, W., and Hommel, B. (Eds). (2002). Common Mechanisms in Perception and Action: Attention and Performance XIX. New York: Oxford University Press, Inc.

Rafiq Jauhary. (2011). Makna Barokah. Tersedia di http://www.rafiqjauhary. Word-press.com.

Sahmiar Pulungan. (2006). Wawasan Tentang Amanah dalam Al-Qur'an. Disertasi Tidak Diterbitkan. Jakarta: Program Pascasarjana Universitas Islam Negeri Syarif Hidayatullah.

Singer, J. (2009). SPSS Paper: Using SAS Proc Mixed to Fit Multilevel Models, Hierarchical Models, and Individual Growth Models. Tersedia di http://www.ats.ucla.edu/stat/spss/paperexamples/singer/default.htm.

Sommer, B. and Sommer B. (1991). A Practical Guide To Behavioral Research: Tools and Techniques ( $3^{\text {rd }}$ ed.). New York: Oxford University Press.

Thomas, R.M. (2003). Blending Qualitative \& Quantitative Research Methods in Thesis and Dissertations. California: Corwin Press, Inc.

Tyrer, D. And Ahmad, F. (2006). Muslim Women and Higher Education: Identities, Experiences and Prospects: A Summary Report. United Kingdom: Oxuniprint.

Zinnbauer, B.J. and Pargament, K.I. (2005). Religiousness and Spirituality. In. Paloutzian, R.F. and Park, C.R. (Eds.). Handbook of The Psychology of Religion and Spirituality. New York: The Guilford Press.

Zunker, V.G. (2002). Career Counseling: Applied Concepts of Life Planning, (Sixth Edition). United Kingdom: Brooks/Cole. 